\title{
Calendula officinalis green-mediated silver nanoparticles: formulation, characterization and assessment of colorectal cancer activities
}

\author{
Dr Yongchao Xu1 ${ }^{1}$, Behnam Mahdavi², Mohammad Mahdi Zangeneh³, Akram Zangeneh33, \\ Maryam Qorbani², Sogand Paydarfard ${ }^{2}$
}

\author{
'Department of General Surgery, Affiliated Cancer Hospital of Zhengzhou University, \\ Zhengzhou, Henan, China \\ 2Department of Chemistry, Faculty of Science, Hakim Sabzevari University, Sabzevar, \\ Iran \\ ${ }^{3}$ Biotechnology and Medicinal Plants Research Center, Ilam University of Medical \\ Sciences, Ilam, Iran
}

Submitted: 14 August 2021; Accepted: 17 September 2021

Online publication: 15 October 2021

Arch Med Sci

DOI: https://doi.org/10.5114/aoms/142350

Copyright $\odot 2021$ Termedia \& Banach

\section{Abstract}

Introduction: The biosynthesis of metal nanoparticles using medicinal plants is not only economical but also environmentally friendly as well as having miscellaneous biomedical applications.

Material and methods: In the present study, silver nanoparticles were green-synthesized using an aqueous extract of Calendula officinalis. The synthesized AgNPs@C. officinalis was characterized by analytical techniques including EDX, FE-SEM, XRD, UV-Vis., and FT-IR. The anti-human colorectal cancer activities of AgNPs@C. officinalis were evaluated using MTT assay. The nanoparticles were formed in a spherical shape in the range of 38.05 to $75.41 \mathrm{~nm}$ for the particle size. On the other hand, the MTT assay was run to evaluate anti colorectal cancer activity of AgNPs@C. officinalis. In the cellular and molecular part of the study, the cells treated with AgNPs@C. officinalis were assessed by MTT assay for $48 \mathrm{~h}$ to determine the cytotoxicity and anti-human colorectal carcinoma properties on normal (HUVEC) and colorectal carcinoma cell lines, i.e. WiDr, SW1417 [SW-1417], and DLD-1.

Results: In the antioxidant test, the IC ${ }_{50}$ values of AgNPs@C. officinalis and BHT against DPPH free radicals were 222 and $124 \mu \mathrm{g} / \mathrm{ml}$, respectively. The viability of the malignant colorectal cell line decreased dose-dependently in the presence of AgNPs@C.officinalis.The IC ${ }_{50}$ values of AgNPs@C.officinalis were 430, 326, and $392 \mu \mathrm{g} / \mathrm{ml}$ against WiDr, SW1417 [SW-1417], and DLD-1 cell lines, respectively.

Conclusions: After the clinical study, silver nanoparticles containing C. officinalis leaf aqueous extract may be used to formulate a new chemotherapeutic drug or supplement to treat several types of human colorectal carcinoma.

Key words: Calendula officinalis, silver nanoparticles, green synthesis, antioxidant, anti-human colorectal cancer, cytotoxicity.

\section{Introduction}

Calendulaofficinalis is well known as a medicinal plant. The plantbelongs to the Asteraceae family [1]. So far, various usages have been reported for C. officinalis [2]. The plant is used for jaundice and blood purification. The plant is an effective agent for sunburn, burns, and dry dermatosis and is
Corresponding author:

Behnam Mahdavi

Department

of Chemistry

Faculty of Science

Hakim Sabzevari

University

96179-76487

Sabzevar, Iran

E-mail: b.mahdavi@hsu.ac.ir 
also known as an anti-inflammatory and wound healing drug $[3,4]$. C. officinalis has antifungal, hypoglycemic, anti-inflammatory, and hypolipidemic properties [2]. The extracts of $C$. officinalis are dominated by various classes of secondary metabolites. The plant is rich in terpenoids, flavonoids, coumarins, saponins, phenolic acids, lipids, and glucosides. The presence of these compounds is the major reason for the ability of $C$. officinalis to cure different diseases [5-7].

Previous studies have indicated that when metallic nanoparticles are green-synthesized by ethnomedicinal plants rich in antioxidant molecules, their therapeutic properties such as anti-human cancer effects significantly increase. Many researchers use chemotherapy to treat several types of cancers [8-11]. Chemotherapeutic supplements exert several side effects on many organs, so today the effective chemotherapeutic drug formulation from nanoparticles is valuable [10-12]. One of the simplest nanostructures that is widely used in industry today is metallic nanoparticles. Metallic nanoparticles can bind non-destructively to single-stranded DNA, which are important in medical diagnostics. Nanoparticles also can pass through the vessel and position the target organ in the body, which is used in biomedicine, imaging and therapy [8-10]. Biomedical applications of nanoparticles include drug carriers, tracking or labeling materials, carriers for gene therapy, hyperthermia, and materials for magnetic resonance imaging. To use nanoparticles to deliver a drug molecule or DNA or a gene in gene therapy, chemical changes at the nanoparticle surface are always required for specific interactions with the desired biomolecule. Nanoparticles are used for imaging for medical purposes or in vitro and in vivo chemical processes. Metallic nanoparticles have received a lot of attention because of their antifungal, photocatalytic and UV absorbing properties [9, 10]. Due to the antibacterial properties of these metal oxide nanoparticles, they can be used in the food industry and active food packaging. Also, metallic nanoparticles are potentially used in hyperthermia, magnetic resonance imaging (MRI), diagnosis and treatment of tumors or cancer, biomarkers, biodegradation, biotechnology and the removal of important organic, inorganic and radioactive contaminants due to their high biocompatibility [8-14]. Metallic nanoparticles have many applications in various fields such as fuel cells (hydrogen, methanol), glucose detection, drug delivery, toxicology, and biological interactions [10, 11]. Metallic nanoparticles as a strong antioxidant resource are much less toxic than metals and also these nanoparticles have high power in scavenging free radicals (FR), so they can be used as natural antioxidants. Studies show that these nanoparticles detoxify hydroperoxidases and lipohydroperoxidases at the cytoplasmic and mitochondrial matrix levels. Metallic nanoparticles such as copper, silver and titanium have very high antimicrobial properties that can be used in various industrial and biomedical sectors [9, 11]. Nanoparticles can also be used as coatings on molecules to bind or interact with biological targets. To ensure the presence of these nanoparticles in the target part of the body, carriers are used to accurately deliver these nanoparticles, in which peptides have been introduced as one of the best carriers [12]. Metallic nanoparticles containing medicinal plants have very significant anti-cancer effects. In recent years, these metal nanoparticles containing herbs have been used to treat various cancers of the ovaries, prostate, esophagus, stomach, lungs, and various leukemias [8-12].

It is predicted that if metal nanoparticles are synthesized and formulated with the plants, their anti-cancer effects against colorectal cancer cells will be much stronger. In the current research, the properties of silver nanoparticles formulated by $\mathrm{Ca}$ lendula officinalis leaf aqueous extract against common colorectal adenocarcinoma cell lines, i.e. WiDr, SW1417 [SW-1417], and DLD-1, were evaluated.

\section{Material and methods}

\section{Materials}

Phosphate buffer solution (PBS), Sabouraud Dextrose Agar, Sabouraud Dextrose Medium, Muller Hinton Agar, Mueller Hinton Medium, carbazole reagent, 4-(dimethylamino)benzaldehyde, Dulbecco's Modified Eagle Medium (DMED), Ehrlich solution, dimethyl sulfoxide (DMSO), hydrolysate, decamplmaneh fetal bovine serum, borax-sulfuric acid mixture, 2,2-diphenyl-1-picrylhydrazyl (DPPH), and antimycotic antibiotic solution were all obtained from Sigma-Aldrich (USA).

\section{Preparation and extraction of aqueous extract}

First, the dried leaves of Calendula officinalis were ground. Then, $80 \mathrm{~g}$ of the sample was macerated in $500 \mathrm{ml}$ of boiling water for $3 \mathrm{~h}$. Next, filtration and evaporation were applied to obtain the concentrated extract. Finally, the extract was put in a freeze drier for $72 \mathrm{~h}$ to produce the powder extract of Calendula officinalis.

\section{Green synthesis and chemical characterization of AgNPs@C. officinalis}

A reported procedure (with some modifications) was used for green-synthesis of AgNPs@. officinalis [8]. First, $25 \mathrm{ml}$ of the plant extract $(0.2 \mathrm{~g}$ in $25 \mathrm{ml}$ of water) was added to $50 \mathrm{ml}$ of 
$0.1 \mathrm{M} \mathrm{AgNO}_{3}$. Then, the mixture was stirred for $24 \mathrm{~h}$ at $30^{\circ} \mathrm{C}$. After this time, the silver nanoparticle was formed. The obtained AgNPs@C. officinalis was washed three times with water:ethanol and centrifuged at $10000 \mathrm{rpm}$ for $15 \mathrm{~min}$. Finally, the precipitate was dried at room temperature. The synthesized nanoparticles as a dark brown powder were kept in a vial for chemical characterization and biological activity evaluation.

\section{Chemical characterization techniques}

Different factors of the nanoparticles such as shape, particle size, fractal dimensions, crystallinity, and surface area are characterized by FT-IR spectroscopy, XRD, SEM, and EDS. In the present study, the FT-IR spectra of the synthetic nanoparticles were recorded by a Shimadzu FT-IR 8400 ranging from 400 to $4000 \mathrm{~cm}^{-1}$ ( $\mathrm{KBr}$ disc); The FE-SEM Images and EDS result were reported using MIRA3TESCAN-XMU. The AgNPs@C. officinalis XRD pattern was recorded in the $2 \theta$ which ranged from 20 to $80^{\circ}$ by a GNR EXPLORER instrument at a $40 \mathrm{KV}$ voltage, a current of $30 \mathrm{~mA}$, and $\mathrm{Cu}-\mathrm{K} \alpha$ radiation (1.5406 $\mathrm{A}$ ).

\section{Antioxidant activities of AgNPs@C. officinalis}

The ability of hydrogen atoms or electrons to give off different compounds and nanoparticles in this test is measured by the degree of decolorization of the 2,2-diphenyl-1-picryl-hydrazyl purple solution in methanol. In this method, DPPH (Sigma-Aldrich) was used as a stable radical compound. Thus, $100 \mu \mathrm{l}$ of various dilutions of nanoparticles in methanol was added to $10 \mathrm{ml}$ of $0.005 \% \mathrm{DPPH}$ solution in methanol. After $1 \mathrm{~h}$ of incubation at the absorption room temperature, the samples were read against blank at $518 \mathrm{~nm}$. The DPPH inhibition percentage was computed by the following formula [15]: Inhibition $(\%)=($ Sample A/Control A $) \times 100$.

In this formula, "Control A" shows the negative control of light absorption that lacks nanoparticles, and "Sample A" expresses the amount of light absorption of different concentrations of nanoparticles [15].

\section{Anti-human colorectal cancer properties of AgNPs@C. officinalis}

In this research, the following cell lines were used to assess the anti-human colorectal carcinoma properties of silver nitrate, $C$. officinalis leaf aqueous extract and AgNPs@C.officinalis using an MTT method.

a) Human colorectal cancer cell lines; WiDr, SW1417 [SW-1417], and DLD-1,

b) Normal cell line: HUVEC.

These cells were maintained in a DMEM medium with $10 \%$ bovine embryos and $1 \%$ penicillin/ streptomycin antibiotic (to prevent fungal growth). Prerequisites for cell growth at $37^{\circ} \mathrm{C}$ are $5 \% \mathrm{CO}_{2}$ with $95 \%$ moisture, which was provided by the NÜVE incubator (EC160 model). For the MTT assay, when the cells reached at least $70 \%$ cell growth, they were separated from the bottom of the flask by trypsin-ethyldiamine tetraacetic acid and centrifuged at $1700 \mathrm{rpm}$ for $6 \mathrm{~min}$. Cell precipitate was prepared in suspension in $1 \mathrm{ml}$ of culture medium. The viability of cells in cell suspension was determined by mixing it with an equal proportion of trypan blue, and counting them with a Neobar slide under a light microscope. After confirming that the cells were not infected, cells with a viability of more than $90 \%$ were used for testing [16]. To investigate the effect of nanoparticles on cancer cell proliferation, the tetrazolium (MTT) salt colorimetric method was used. For this test, $10^{4}$ cells were added to each well of a 96-well plate. After $24 \mathrm{~h}$ of incubation, concentrations of $1-1000 \mu \mathrm{g} /$ $\mathrm{ml}$ were treated on cancer and normal cells for 24, 48 and $72 \mathrm{~h}$. After these times, $20 \mu \mathrm{l}$ of MTT solution and $200 \mu$ l of base culture medium were added to each well. The plate was placed in a dark $\mathrm{CO}_{2}$ incubator at $37^{\circ} \mathrm{C}$ for $4 \mathrm{~h}$ in the dark. After this time, $100 \mu$ l of DMSO was added to each well. 492 and $630 \mathrm{~nm}$ optical readings were placed in the ELISA reader (DANA model DA3200). The cell viability was computed by the following formula [16]: Cell viability $(\%)=($ Sample $A /$ Control $A) \times 100$.

To compare the results, in addition to the formula mentioned above, which was calculated as an average of 5 repetitions of experiments, the results were analyzed using SPSS software version 22 and the statistical differences between the treatments were examined by $t$-test.

\section{Results and Discussion}

\section{Chemical characterization of AgNPs@C. officinalis}

\section{XRD analysis}

The XRD diffraction patterns of AgNPs@C. officinalis evaluated its crystallinity. The pattern of the diffractogram is shown in Figure 1. The formation of

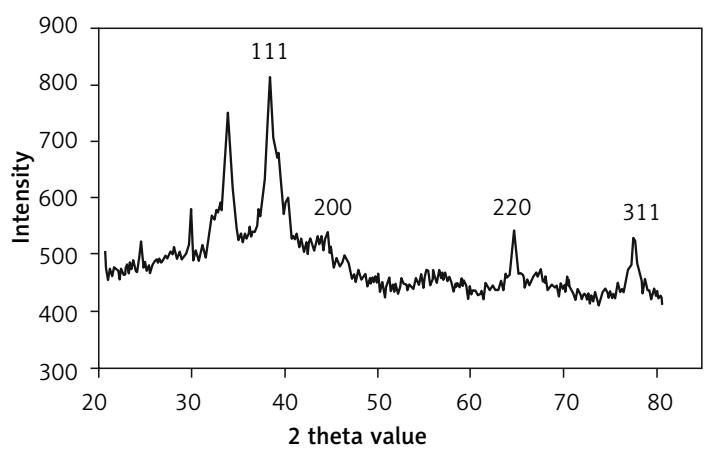

Figure 1. XRD Pattern of AgNPs@C. officinalis 
nanoparticles was confirmed by this result. Despite the small size of AgNPs@C. officinalis, the pattern of XRD indicated well crystallization. The achieved data were compared with the standard database of JCPD card 04-0783. The signals with $2 \theta$ values of $38.325,44.915,64.655$, and 77.735 are indexed as (111), (200), (220), and (311) planes. $43.49 \mathrm{~nm}$ was measured for the crystal size of AgNPs@C.officinalis that was calculated using X-ray diffraction and according to Scherer's equation. Various crystalline sizes have been determined according to XRD analysis for the biosynthesized AgNPs using plant extracts: $27.18 \mathrm{~nm}$ for Salvia leriifolia leaf extract [17]; $18 \mathrm{~nm}$ for Caesalpinia pulcherrima extract [18]; 45 $\mathrm{nm}$ for Phyllanthus emblica extract [19]; $50 \mathrm{~nm}$ for Berberis vulgaris extract [20]; and $5 \mathrm{~nm}$ for Selaginella bryopteris extract [21].

\section{SEM analysis}

The morphology of AgNPs@C. officinalis was assessed by the FE-SEM technique. Figure 2 presents the FE-SEM of AgNPs@C. officinalis. The images show the spherical shape for the nanopar-

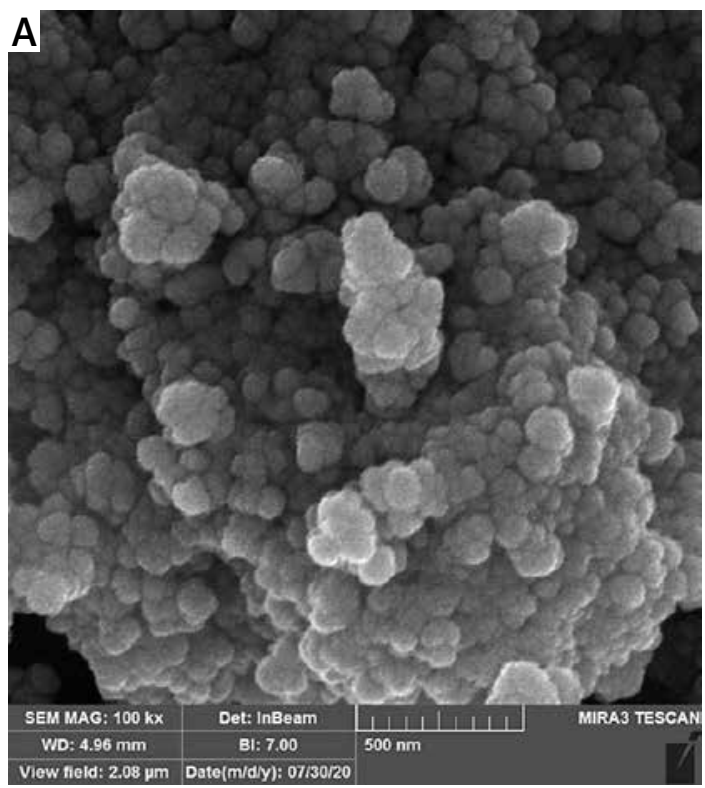

Figure 2. SEM Images of ZnNPs@C. officinalis

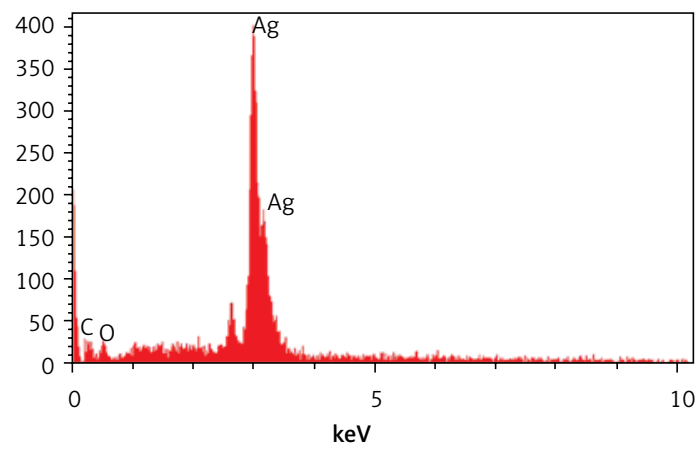

Figure 3. EDS analysis of AgNPs@C. officinalis ticles with particle size in the range of 22.43 to $57.57 \mathrm{~nm}$. Furthermore, the nanoparticles are aggregated. This is a general property of the green synthesized metallic nanoparticles, which was found in our literature review [17, 22-24]. In our review of the literature, the size of silver nanoparticles which were synthesized using plant extract was in the range of 5 to $251.1 \mathrm{~nm}$ [9-21].

\section{EDS analysis}

The qualitative analysis of EDS was run to screen the elemental analysis of AgNPs@C. officinalis. The EDS diagram of AgNPs is shown in Figure 3. The findings confirmed the presence of silver (by the peak at $3.02 \mathrm{keV}$ for AgL $\alpha$ and the peak at $3.19 \mathrm{keV}$ for $\mathrm{AgL} \beta$ ), oxygen (by the peak around $0.5 \mathrm{keV}$ for $\mathrm{OL} \alpha$ ), and carbon (by the peak around $0.3 \mathrm{keV}$ for CL $\alpha$ ) in AgNPs@C. officinalis. The signal for silver has been reported by other research groups [21]. The presence of oxygen and carbon confirmed the linkage between silver nanoparticles and organic compounds of the plant extract.
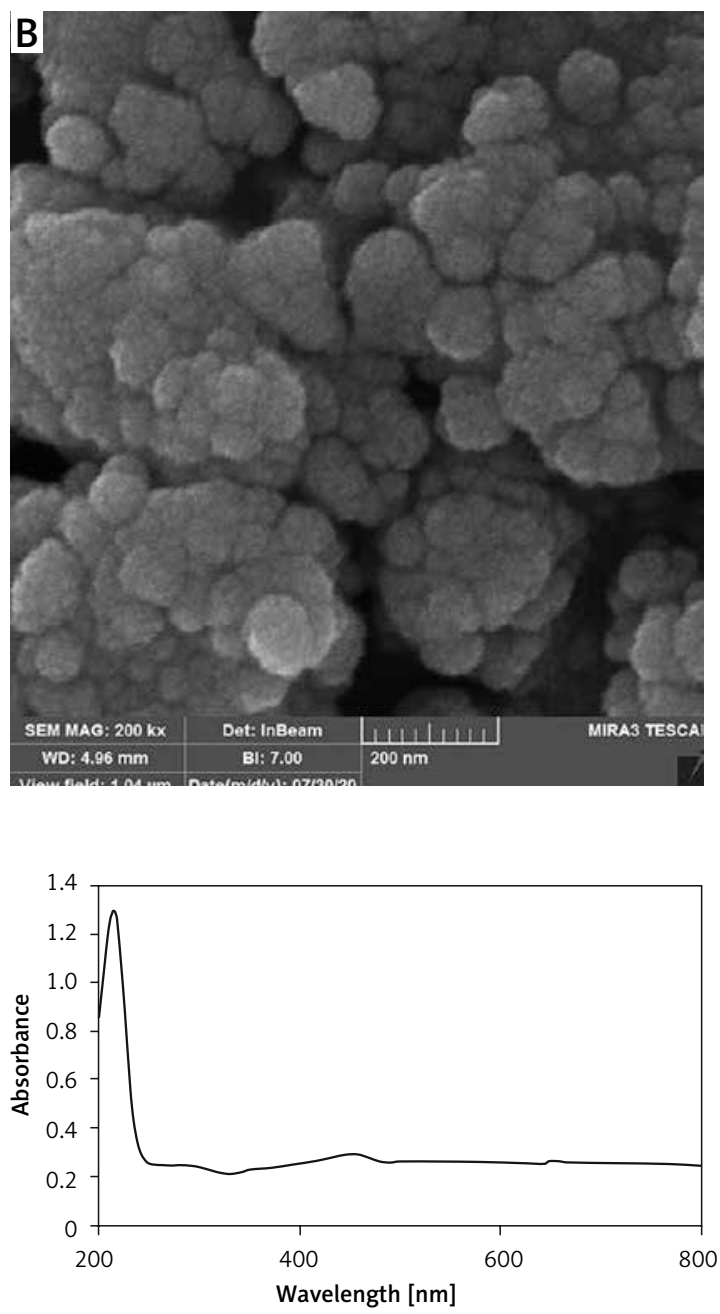

Figure 4. UV-Vis. spectrum of biosynthesized AgNPs@C. officinalis 


\section{UV-Vis. analysis}

The UV-Vis. spectrum of the green-synthetic nanoparticles of AgNPs@C. officinalis is presented in Figure 4. The surface plasmon resonance (SPR) of AgNPs@C. officinalis was completed using UVVis. spectroscopy. The produce of the biosynthetic AgNPs@C. officinalis was observed. The advanced SPR bands at the wavelength of $452 \mathrm{~nm}$ proved the formation of the silver nanoparticles. The bands are very close to a previous report on the green synthesis of silver nanoparticles using Fritillaria extract [25].

\section{FT-IR analysis}

The FT-IR spectrum of silver nanoparticles is shown in Figure 5. The formation of AgNPs@.officinalis is proved by the presence of the peaks at wavenumbers 513, 582 and $640 \mathrm{~cm}^{-1}$. Similar peaks with some differences in the wavenumber have been reported for green-synthetic AgNPs by other research groups [21]. The other peaks in the spectrum are attributed to the functional groups of different organic compounds in C. officinalis extract, which are linked to the surface of AgNPs@C. officinalis. The presence of secondary metabolites such as phenolic, flavonoid, saponins, quinones, terpenoids in $C$. officinalis extract has been reported previously $[2,4,7,26]$. The peaks at 3423 and $2921 \mathrm{~cm}^{-1}$ are related to $\mathrm{O}-\mathrm{H}$ and aliphatic $\mathrm{C}-\mathrm{H}$ stretching; the peaks from 1550 to $1683 \mathrm{~cm}^{-1}$ correspond to $\mathrm{C}=\mathrm{C}$ and $\mathrm{C}=\mathrm{O}$ stretching, and the peaks at $1010 \mathrm{~cm}^{-1}$ could be ascribed to $\mathrm{C}-\mathrm{O}$ and $\mathrm{C}-\mathrm{O}-\mathrm{C}$ stretching vibrations.

\section{Cytotoxicity, anti-human colorectal cancer, and antioxidant activities of AgNPs@ Calendula officinalis}

With the advances in life sciences, measuring the rate of proliferation, survival and cell mortality under different conditions has become very important. In this regard, MTT analysis has greatly contributed to the study of biocompatibility of various materials by providing a highly safe non-radioactive colorimetric system. Cytotoxicity tests are tests that examine the side effects of various compounds on the cell. These processes take place in the environment outside the human body, called extracorporeal. Most of these processes also use cell culture. In MTT analysis according to the ISO 10993-5 international standard, different types of equipment are tested for cytotoxicity; if they do not have toxic effects, they will obtain the necessary standards and licenses and enter the buying and selling market. The MTT set is the best-known test for cell viability. The main purpose of this test is to evaluate the toxicity of compounds, drugs or other supplements

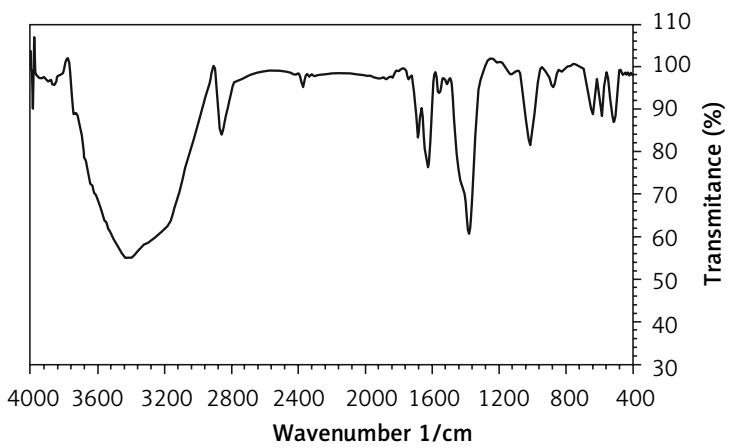

Figure 5. FT-IR spectrum of biosynthesized AgNPs@C. officinalis

on the cell. Of course, it may also be mentioned in articles as a process for examining cell proliferation or counting [27-29]. MTT analysis can differentiate between living and dead cells by affecting intracellular organs. In this method, the cells, after being cultured in the laboratory, are "treated" with the desired substances to evaluate their toxicity. At the end of this test, for each concentration of the substance, the cell viability is determined. Although this method is primarily for water-soluble solutions and compounds, it is currently used for other compounds soluble in organic solvents and nanoparticles. The behavior and rate of cell proliferation may increase or not change at all under the influence of hormones, growth factors, cytokines and mitogens. Also, some drugs and cytotoxic (toxic) substances, such as anticancer drugs, may cause necrosis or apoptosis (death) of cells or slow down the rate of proliferation and growth or even cause loss of cell structure [28-31]. Proper analysis of the MTT test can evaluate many of these behaviors. The MTT analysis is based on mitochondrial activity. This activity is usually stable in living cells. Hence, any change in several active and living cells is linked to mitochondrial properties. This examination is a colorimetric method based on the breakdown and reduction of yellow tetrazolium crystals by succinate dehydrogenase and the formation of insoluble purple crystals in the final analysis. Unlike other methods, MTT analysis eliminates the cell washing and shrinking steps, which usually cause the loss of some cells and increase the work error. That is, all the steps of the experiment, from the cell culture beginning to reading and analyzing the findings with a photometer, are done in a completely compact way and in a "micro plate". Hence the sensitivity, accuracy, and repeatability of the test are high [30-32].

In this study, the cells treated with different concentrations of the silver nitrate, $C$. officinalis leaf aqueous extract, and AgNPs@C. officinalis were assessed by MTT assay for $48 \mathrm{~h}$ to determine the cytotoxicity properties on normal (HUVEC) and colorectal malignancy cell lines, i.e. WiDr, SW1417 [SW-1417], and DLD-1. 
Table I. Anti-colorectal cancer properties of $\mathrm{AgNO}_{3}$, AgNPs@C. officinalis, and C. officinalis leaf aqueous extract against human colorectal cancer cell lines

\begin{tabular}{|c|c|c|c|c|}
\hline \multirow[t]{2}{*}{ Concentration $[\mu \mathrm{g} / \mathrm{ml}]$} & \multicolumn{4}{|c|}{ Cell viability (\%) } \\
\hline & WiDr & $\begin{array}{c}\text { SW1417 } \\
\text { [SW-1417] }\end{array}$ & DLD-1 & HUVEC \\
\hline $\mathrm{AgNO}_{3}(0)$ & $100 \pm 0^{\mathrm{a}}$ & $100 \pm 0^{\mathrm{a}}$ & $100 \pm 0^{\mathrm{a}}$ & $100 \pm 0^{\mathrm{a}}$ \\
\hline $\mathrm{AgNO}_{3}(1)$ & $100 \pm 0^{\mathrm{a}}$ & $100 \pm 0^{\mathrm{a}}$ & $100 \pm 0^{\mathrm{a}}$ & $100 \pm 0^{\mathrm{a}}$ \\
\hline $\mathrm{AgNO}_{3}(2)$ & $100 \pm 0^{\mathrm{a}}$ & $100 \pm 0^{\mathrm{a}}$ & $100 \pm 0^{\mathrm{a}}$ & $100 \pm 0^{\mathrm{a}}$ \\
\hline $\mathrm{AgNO}_{3}(3)$ & $100 \pm 0^{\mathrm{a}}$ & $100 \pm 0^{\mathrm{a}}$ & $100 \pm 0^{\mathrm{a}}$ & $100 \pm 0^{\mathrm{a}}$ \\
\hline $\mathrm{AgNO}_{3}(7)$ & $100 \pm 0^{\mathrm{a}}$ & $100 \pm 0^{\mathrm{a}}$ & $100 \pm 0^{\mathrm{a}}$ & $100 \pm 0^{\mathrm{a}}$ \\
\hline $\mathrm{AgNO}_{3}(15)$ & $100 \pm 0^{\mathrm{a}}$ & $100 \pm 0^{\mathrm{a}}$ & $100 \pm 0^{\mathrm{a}}$ & $100 \pm 0^{\mathrm{a}}$ \\
\hline $\mathrm{AgNO}_{3}(31)$ & $100 \pm 0^{a}$ & $99.2 \pm 0.44^{a}$ & $100 \pm 0^{a}$ & $98.4 \pm 0.54^{a}$ \\
\hline $\mathrm{AgNO}_{3}(62)$ & $98.4 \pm 1.34^{a}$ & $95.2 \pm 0.83^{a}$ & $100 \pm 0^{a}$ & $95 \pm 1^{a}$ \\
\hline $\mathrm{AgNO}_{3}(125)$ & $94.6 \pm 0.89^{a}$ & $88.4 \pm 1.34^{\mathrm{a}}$ & $97.2 \pm 0.83^{a}$ & $91.6 \pm 0.89^{a}$ \\
\hline $\mathrm{AgNO}_{3}(250)$ & $89 \pm 1.22^{\mathrm{a}}$ & $79.4 \pm 0.54^{\text {ab }}$ & $90 \pm 0.7^{a}$ & $85.6 \pm 0.89^{a}$ \\
\hline $\mathrm{AgNO}_{3}(500)$ & $81 \pm 1^{\mathrm{ab}}$ & $66.4 \pm 0.54^{\mathrm{ab}}$ & $83.8 \pm 0.44^{a}$ & $77 \pm 1.22^{\mathrm{ab}}$ \\
\hline $\mathrm{AgNO}_{3}(1000)$ & $68.2 \pm 1.3^{\text {ab }}$ & $53.6 \pm 0.89^{b}$ & $70.4 \pm 1.34^{\mathrm{ab}}$ & $62.2 \pm 0.83^{\mathrm{ab}}$ \\
\hline C. officinalis (0) & $100 \pm 0^{\mathrm{a}}$ & $100 \pm 0^{\mathrm{a}}$ & $100 \pm 0^{\mathrm{a}}$ & $100 \pm 0^{\mathrm{a}}$ \\
\hline C. officinalis (1) & $100 \pm 0^{a}$ & $100 \pm 0^{\mathrm{a}}$ & $100 \pm 0^{a}$ & $100 \pm 0^{\mathrm{a}}$ \\
\hline C. officinalis (2) & $100 \pm 0^{a}$ & $100 \pm 0^{\mathrm{a}}$ & $100 \pm 0^{a}$ & $100 \pm 0^{\mathrm{a}}$ \\
\hline C. officinalis (3) & $100 \pm 0^{\mathrm{a}}$ & $100 \pm 0^{\mathrm{a}}$ & $100 \pm 0^{\mathrm{a}}$ & $100 \pm 0^{a}$ \\
\hline C. officinalis (7) & $100 \pm 0^{a}$ & $100 \pm 0^{a}$ & $100 \pm 0^{a}$ & $100 \pm 0^{\mathrm{a}}$ \\
\hline C. officinalis (15) & $100 \pm 0^{\mathrm{a}}$ & $100 \pm 0^{\mathrm{a}}$ & $100 \pm 0^{a}$ & $100 \pm 0^{\mathrm{a}}$ \\
\hline C. officinalis (31) & $100 \pm 0^{\mathrm{a}}$ & $100 \pm 0^{\mathrm{a}}$ & $100 \pm 0^{\mathrm{a}}$ & $100 \pm 0^{\mathrm{a}}$ \\
\hline C. officinalis (62) & $97.6 \pm 0.89^{\mathrm{a}}$ & $96.4 \pm 1.34^{\mathrm{a}}$ & $97.4 \pm 0.89^{a}$ & $100 \pm 0^{\mathrm{a}}$ \\
\hline C. officinalis (125) & $92.4 \pm 0.54^{a}$ & $90 \pm 1^{\text {a }}$ & $92 \pm 1.22^{\mathrm{a}}$ & $99.2 \pm 0.44^{a}$ \\
\hline C. officinalis (250) & $80.6 \pm 0.89^{\mathrm{ab}}$ & $74 \pm 0.7^{\mathrm{ab}}$ & $79.2 \pm 1.3^{\mathrm{ab}}$ & $98 \pm 0.7^{a}$ \\
\hline C. officinalis (500) & $64 \pm 1^{\mathrm{ab}}$ & $58.4 \pm 0.89^{b}$ & $60.6 \pm 0.89^{b c}$ & $96 \pm 1^{a}$ \\
\hline C. officinalis (1000) & $47 \pm 1.22^{b}$ & $34.2 \pm 1.3^{\mathrm{bc}}$ & $35.8 \pm 0.44^{\text {bc }}$ & $91.8 \pm 0.44^{a}$ \\
\hline AgNPs@C.officinalis (0) & $100 \pm 0^{\mathrm{a}}$ & $100 \pm 0^{\mathrm{a}}$ & $100 \pm 0^{a}$ & $100 \pm 0^{\mathrm{a}}$ \\
\hline AgNPs@C.officinalis (1) & $100 \pm 0^{a}$ & $100 \pm 0^{a}$ & $100 \pm 0^{a}$ & $100 \pm 0^{\mathrm{a}}$ \\
\hline AgNPs@C. officinalis (2) & $100 \pm 0^{a}$ & $100 \pm 0^{a}$ & $100 \pm 0^{a}$ & $100 \pm 0^{\mathrm{a}}$ \\
\hline AgNPs@C. officinalis (3) & $100 \pm 0^{\mathrm{a}}$ & $100 \pm 0^{\mathrm{a}}$ & $100 \pm 0^{a}$ & $100 \pm 0^{\mathrm{a}}$ \\
\hline AgNPs@C. officinalis (7) & $100 \pm 0^{\mathrm{a}}$ & $100 \pm 0^{\mathrm{a}}$ & $100 \pm 0^{a}$ & $100 \pm 0^{\mathrm{a}}$ \\
\hline AgNPs@C. officinalis (15) & $99.6 \pm 0.89^{a}$ & $98 \pm 0.7^{a}$ & $100 \pm 0^{a}$ & $100 \pm 0^{\mathrm{a}}$ \\
\hline AgNPs@C. officinalis (31) & $95.4 \pm 0.54^{a}$ & $92.2 \pm 0.44^{a}$ & $97 \pm 1^{a}$ & $99.8 \pm 0.44^{a}$ \\
\hline AgNPs@C. officinalis (62) & $88.4 \pm 0.54^{a}$ & $84.4 \pm 1.34^{\mathrm{a}}$ & $90.4 \pm 1.34^{a}$ & $98.6 \pm 0.89^{a}$ \\
\hline AgNPs@C. officinalis (125) & $77.6 \pm 0.89^{\mathrm{ab}}$ & $70 \pm 1.22^{\mathrm{ab}}$ & $77.2 \pm 1.3^{\mathrm{ab}}$ & $95 \pm 0.7^{a}$ \\
\hline AgNPs@C. officinalis (250) & $61.4 \pm 1.34^{\mathrm{b}}$ & $54.8 \pm 0.44^{b}$ & $60 \pm 1^{b}$ & $90.4 \pm 0.89^{a}$ \\
\hline AgNPs@C. officinalis (500) & $45.6 \pm 0.89^{b}$ & $39.2 \pm 0.44^{\text {bc }}$ & $42.4 \pm 1.34^{\mathrm{bc}}$ & $84 \pm 1.22^{\mathrm{a}}$ \\
\hline AgNPs@C. officinalis (1000) & $22 \pm 1^{c}$ & $11.2 \pm 1.3^{c}$ & $14.4 \pm 0.54^{c}$ & $77 \pm 1^{\text {ab }}$ \\
\hline
\end{tabular}

Different letters indicate significant differences between experimented groups $(p \leq 0.01)$.

Table II. The $\mathrm{IC}_{50}$ values of $\mathrm{AgNO}_{3}$, AgNPs@C. officinalis, and C. officinalis leaf aqueous extract in cytotoxicity and anti-colorectal cancer tests

\begin{tabular}{|lccc|}
\hline Variable & $\mathrm{AgNO}_{3}[\mu \mathrm{g} / \mathrm{ml}]$ & AgNPs@C. officinalis $[\mu \mathrm{g} / \mathrm{ml}]$ & C. officinalis $[\mu \mathrm{g} / \mathrm{ml}]$ \\
\hline $\mathrm{IC}_{50}$ against WiDr & - & $430 \pm 0^{\mathrm{c}}$ & $911 \pm 0^{\mathrm{a}}$ \\
\hline $\mathrm{IC}_{50}$ against SW1417 [SW-1417] & - & $326 \pm 0^{\mathrm{d}}$ & $673 \pm 0^{\mathrm{b}}$ \\
\hline $\mathrm{IC}$ & - & $392 \pm 0^{\mathrm{cd}}$ & $713 \pm 0^{\mathrm{b}}$ \\
\hline $\mathrm{I} \mathrm{C}_{50}$ against DLD-1 & - & - & - \\
\hline
\end{tabular}

Different letters indicate significant differences between experimented groups $(p \leq 0.01)$. 
The viability of the malignant colorectal cell lines decreased dose-dependently in the presence of silver nitrate, Calendula officinalis leaf aqueous extract, and AgNPs@C. officinalis. The $\mathrm{IC}_{50}$ values of AgNPs@C.officinalis were 430,326, and 392 Mg/ $\mathrm{ml}$ against WiDr, SW1417 [SW-1417], and DLD-1 cell lines, respectively (Tables I, II). The $I C_{50}$ values of $C$. officinalis leaf aqueous extract were 911,673 , and $713 \mu \mathrm{g} / \mathrm{ml}$ against WiDr, SW1417 [SW-1417], and DLD-1 cell lines, respectively (Tables I, II).

The absorbance rate was evaluated at $570 \mathrm{~nm}$, which represented viability on the normal cell line (HUVEC) even up to $1000 \mu \mathrm{g} / \mathrm{ml}$ for silver nitrate, C. officinalis leaf aqueous extract, and AgNPs@C. officinalis (Tables I, II).

In this study, we determined the AgNPs@C. officinalis antioxidant properties by the free radical
(DPPH) test. Free radicals (FRs) are unstable molecules or atoms that have an unpaired electron. FRs are formed by breaking a bond of a stable molecule. This property increases their chemical reactions. The main important $\mathrm{FR}$ in humans is $\mathrm{O}_{2}$. Oxygen molecules are exposed to various forms of radiation, stress, and smoke from smoking, etc. By taking an electron from other molecules, it destroys other molecules, cells and DNA. Wherever FRs are mentioned, antioxidants are the main way to fight them and regenerate damaged cells [9-11]. Antioxidants destroy FRs and increase the body's immunity against a variety of diseases. Antioxidants are compounds that eliminate the threat of FRs to cell life by preventing the production of FRs or converting them into less active forms. In inflammatory processes in the body,

Table III. Antioxidant activities of $\mathrm{AgNO}_{3}$, AgNPs@C. officinalis, C. officinalis leaf aqueous extract, and butylated hydroxyl toluene against DPPH

\begin{tabular}{|c|c|}
\hline Concentration $[\mu \mathrm{g} / \mathrm{ml}]$ & DPPH inhibition (\%) \\
\hline $\mathrm{AgNO}_{3}(0)$ & $0 \pm 0^{a}$ \\
\hline $\mathrm{AgNO}_{3}(1)$ & $0 \pm 0^{a}$ \\
\hline $\mathrm{AgNO}_{3}(2)$ & $0 \pm 0^{\mathrm{a}}$ \\
\hline $\mathrm{AgNO}_{3}(3)$ & $1.2 \pm 0.83^{\mathrm{a}}$ \\
\hline $\mathrm{AgNO}_{3}(7)$ & $2 \pm 1^{a}$ \\
\hline $\mathrm{AgNO}_{3}(15)$ & $4.2 \pm 0.83^{\mathrm{a}}$ \\
\hline $\mathrm{AgNO}_{3}(31)$ & $8.2 \pm 0.83^{a}$ \\
\hline $\mathrm{AgNO}_{3}(62)$ & $12.2 \pm 1.3^{\mathrm{a}}$ \\
\hline $\mathrm{AgNO}_{3}(125)$ & $18.2 \pm 0.83^{\mathrm{a}}$ \\
\hline $\mathrm{AgNO}_{3}(250)$ & $25 \pm 1^{\text {ab }}$ \\
\hline $\mathrm{AgNO}_{3}(500)$ & $35 \pm 1.22^{\mathrm{ab}}$ \\
\hline $\mathrm{AgNO}_{3}(1000)$ & $48.8 \pm 0.44^{b}$ \\
\hline AgNPs@C. officinalis (0) & $0 \pm 0^{a}$ \\
\hline AgNPs@C. officinalis (1) & $0 \pm 0^{a}$ \\
\hline AgNPs@C.officinalis (2) & $2.4 \pm 0.89^{\mathrm{a}}$ \\
\hline AgNPs@C. officinalis (3) & $4.2 \pm 0.44^{a}$ \\
\hline AgNPs@C.officinalis (7) & $7.4 \pm 1.34^{\mathrm{a}}$ \\
\hline AgNPs@C. officinalis (15) & $12.4 \pm 1.34^{\mathrm{a}}$ \\
\hline AgNPs@C. officinalis (31) & $18 \pm 1^{\text {a }}$ \\
\hline AgNPs@C. officinalis (62) & $27 \pm 1^{\text {ab }}$ \\
\hline AgNPs@C. officinalis (125) & $39.2 \pm 0.83^{\text {ab }}$ \\
\hline AgNPs@C. officinalis (250) & $53.2 \pm 1.3^{b}$ \\
\hline AgNPs@C. officinalis (500) & $70.2 \pm 0.83^{\text {bc }}$ \\
\hline AgNPs@C. officinalis (1000) & $100 \pm 0^{c}$ \\
\hline
\end{tabular}

\begin{tabular}{|lc|}
\hline Concentration $[\mu \mathrm{g} / \mathrm{ml}]$ & DPPH inhibition (\%) \\
\hline C. officinalis (0) & $0 \pm 0^{\mathrm{a}}$ \\
\hline C. officinalis (1) & $0 \pm 0^{\mathrm{a}}$ \\
\hline C. officinalis (2) & $1.2 \pm 0.83^{\mathrm{a}}$ \\
\hline C. officinalis (3) & $3.4 \pm 1.34^{\mathrm{a}}$ \\
\hline C. officinalis (7) & $6.2 \pm 0.83^{\mathrm{a}}$ \\
\hline C. officinalis (15) & $10 \pm 1^{\mathrm{a}}$ \\
\hline C. officinalis (31) & $15.4 \pm 0.89^{\mathrm{a}}$ \\
\hline C. officinalis (62) & $24.2 \pm 1.3^{\mathrm{ab}}$ \\
\hline C. officinalis (125) & $35.2 \pm 0.83^{\mathrm{ab}}$ \\
\hline C. officinalis (250) & $47.2 \pm 0.44^{\mathrm{b}}$ \\
\hline C. officinalis (500) & $62 \pm 1.22^{\mathrm{bc}}$ \\
\hline C. officinalis (1000) & $83.2 \pm 0.83^{\mathrm{c}}$ \\
\hline BHT (0) & $0 \pm 0^{\mathrm{a}}$ \\
\hline BHT (1) & $0 \pm 0^{\mathrm{a}}$ \\
\hline BHT (2) & $1 \pm 1.22^{\mathrm{a}}$ \\
\hline BHT (3) & $3.4 \pm 0.89^{\mathrm{a}}$ \\
\hline BHT (7) & $7.2 \pm 0.83^{\mathrm{a}}$ \\
\hline BHT (15) & $14.2 \pm 0.44^{\mathrm{a}}$ \\
\hline BHT (31) & $23.2 \pm 0.83^{\mathrm{ab}}$ \\
\hline BHT (62) & $35.4 \pm 1.34^{\mathrm{ab}}$ \\
\hline BHT (125) & $50.2 \pm 0.83^{\mathrm{b}}$ \\
\hline BHT (250) & $70 \pm 1^{\mathrm{bc}}$ \\
\hline BHT (500) & $100 \pm 0^{\mathrm{c}}$ \\
\hline BHT (1000) & $100 \pm 0^{\mathrm{c}}$ \\
\hline
\end{tabular}

Different letters indicate significant differences between experimented groups $(p \leq 0.01)$.

Table IV. $\mathrm{IC}_{50}$ values of $\mathrm{AgNO}_{3}$, AgNPs@C. officinalis, C. officinalis leaf aqueous extract, and butylated hydroxyl toluene in the antioxidant test

\begin{tabular}{|lcccc|}
\hline Concentration $[\mu \mathrm{g} / \mathrm{ml}]$ & $\mathrm{AgNO}_{3}$ & AgNPs@C. officinalis & C. officinalis & BHT \\
\hline $\mathrm{IC}_{50}[\mu \mathrm{g} / \mathrm{ml}]$ & - & $222 \pm 0^{\mathrm{b}}$ & $447 \pm 0^{\mathrm{a}}$ & $124 \pm 0^{\mathrm{c}}$ \\
\hline
\end{tabular}

Different letters indicate significant differences between experimented groups $(p \leq 0.01)$. 
large amounts of superoxide anion radicals are produced by phagocytes. Macrophages and neutrophils produce superoxide and $\mathrm{H}_{2} \mathrm{O}_{2}$ radicals to defend against microorganisms [8, 9]. In such cases, the presence of antioxidants is necessary to modify reactions in which $F$ Rs are produced and to prevent the harmful effects of reactive oxygen species and to prevent damage to immune cells. Antioxidants are used as anti-aging and anti-cancer agents and against cardiovascular, mitochondrial, Huntington's and nerve-destroying diseases such as Parkinson's. In addition, oral administration of some antioxidants is a supplement to increase energy and strengthen the immune system. Primary sources of natural antioxidants are legumes, fruits and vegetables, identified as dietary antioxidants and potentially reducing disease. Given that the synthetic antioxidants used, such as BHT, can be carcinogenic as well as hepatotoxic, over the last two decades, the tendency of consumers to use natural resources to produce antioxidants has increased and attracted a great deal of attention [11, 15, 33, 34].

The scavenging capacity of $C$. officinalis leaf aqueous extract green-synthesized AgNPs@C. officinalis and $\mathrm{BHT}$ at different concentrations expressed as percentage inhibition is presented in Tables III, IV.

In the antioxidant test, the $I C_{50}$ values of $C$. of ficinalis leaf aqueous extract, AgNPs@C. officinalis, and BHT against DPPH free radicals were 447, 222, and $124 \mu \mathrm{g} / \mathrm{ml}$, respectively (Tables III, IV).

In conclusion, we have introduced a green method to synthesize silver nanoparticles for the first time using the extract of $C$. officinalis. The structural features of nanoparticles were evaluated through various analytical techniques such as FT-IR, XRD, FE-SEM, and EDS analyses. The techniques confirmed that AgNPs@C. officinalis had been synthesized in the best possible condition. The viability of the malignant colorectal cell line decreased dose-dependently in the presence of AgNPs@C.officinalis. The IC $1 \mathrm{C}_{50}$ values of AgNPs@C. officinalis were 430,326 , and $392 \mu \mathrm{g} / \mathrm{mL}$ against WiDr, SW1417 [SW-1417], and DLD-1 cell lines, respectively. The AgNPs@C. officinalis showed the best antioxidant activities against DPPH. The IC values of AgNPs@C. officinalis and BHT against DPPH free radicals were 222 and $124 \mu \mathrm{g} / \mathrm{mL}$, respectively. After the clinical study, AgNPs@C. officinalis containing $C$. officinalis leaf aqueous extract can be utilized as an efficient drug to treat the colorectal cancer in humans.

\section{Conflict of interest}

There is no conflict of interest.

\section{References}

1. Rahmani N, Taherkhani T, Zandi P, Aghdam AM. Effect of regulated deficit irrigation and nitrogen levels on flavonoid content and extract performance of marigold (Calendula officinalis L.). J Biol Res 2012; 3: 2624-30.

2. Verma PK, Raina R, Agarwal S, Kaur H. Phytochemical ingredients and pharmacological potential of Calendula officinalis Linn. Pharm Biomed Res 2018; 4: 1-17.

3. Givol O, Kornhaber R, Visentin D, Cleary M, Haik J, Harats $M$. A systematic review of Calendula officinalis extract for wound healing. Wound Repair Regeneration 2019; 27: 548-61.

4. de Oliveira Carvalho H, Góes LDM, Cunha NMB, et al. Development and standardization of capsules and tablets containing Calendula officinalis $L$. hydroethanolic extract. Rev Latinoam Química 2018; 46: 16-27.

5. Tung YT, Wu MF, Lee MC, Wu JH, Huang CC, Huang WC. Antifatigue activity and exercise performance of phenolic-rich extracts from calendula officinalis, Ribes nigrum, and Vaccinium myrtillus. Nutrients 2019; 11: 1715.

6. Al-Mussawi ZK, Al-Hussani IM. Phytochemical study of Calendula officinalis plant by used Gc-Ms and FTIR techniques. Plant Arch 2019; 19: 845-51.

7. Markowski M, Długosz M, Szakiel A, et al. Increased synthesis of a new oleanane-type saponin in hairy roots of marigold (Calendula officinalis) after treatment with jasmonic acid. Natural Product Res 2019; 33: 1218-22.

8. Kooti W, Servatyari K, Behzadifar M, et al. Effective medicinal plant in cancer treatment, part 2: review study. J Evid Based Complementary Altern Med 2017; 22: 98295.

9. Zou M, Zhong Z, Wen C. Characterization and anti-acute myeloid leukemia and anti-acute $T$ cell leukemia properties of zinc nanoparticles synthesized by a green approach for bioremediation applications. Arch Med Sci 2021; DOI: https://doi.org/10.5114/aoms/140295.

10. Ye J, Shi J, Zhang $M$, et al. Novel Alhagi maurorum leaves mediated synthesis of titanium nanoparticles for human breast carcinoma applications: a preclinical trial study. Arch Med Sci 2021; DOI: https://doi. org/10.5114/aoms/134309

11. Mahdavi B, Paydarfard S, Zangeneh MM, Goorani S, Seydi N. Assessment of antioxidant, cytotoxicity, antibacterial, antifungal, and cutaneous wound healing activities of green synthesized manganese nanoparticles using Ziziphora clinopodioides Lam leaves under in vitro and in vivo condition. Appl Organometal Chem 2020; 34: e5248.

12. Hummers WS, Offeman RE.Preparation of graphitic oxide. J Am Chem Soc 1958; 80: 1339-9.

13. Adham AN, Naqishbandi AM, Efferth T. Cytotoxicity and apoptosis induction by Fumaria officinalis extracts in leukemia and multiple myeloma cell lines. J Ethnopharmacol 2021; 266: 113458

14. Edziri H, Guerrab M, Anthonissen R, Mastouri M, Verschaeve L. Phytochemical screening, antioxidant, anticoagulant and in vitro toxic and genotoxic properties of aerial parts extracts of Fumaria officinalis L. growing in Tunisia. South Afr J Botany 2020; 130: 268-73.

15. Aman S, Gupta UK, Singh D, et al. Herbal treatment for the ovarian cancer. SGVU J Pharm Res Educ 2018; 3: 325-9.

16. Arunachalam KD, Annamalai SK, Hari S. One-step green synthesis and characterization of leaf extract-mediated biocompatible silver and gold nanoparticles from Memecylon umbellatum. Int J Nanomedicine. 2003; 8: 1307-15. 
17. Baghayeri M, Mahdavi B, Hosseinpor-Mohsen Abadi Z, Farhadi S. Green synthesis of silver nanoparticles using water extract of Salvia leriifolia: Antibacterial studies and applications as catalysts in the electrochemical detection of nitrite. Appl Organometal Chem 2018; 32: e4057.

18. Deepika S, Selvaraj Cl, Roopan SM. Screening bioactivities of Caesalpinia pulcherrima L. swartz and cytotoxicity of extract synthesized silver nanoparticles on HCT116 cell line. Mater Sci Eng C Biol Appl 2020; 106: 110279.

19. Renuka R, Devi KR, Sivakami M, Thilagavathi T, Uthrakumar R, Kaviyarasu K. Biosynthesis of silver nanoparticles using Phyllanthus emblica fruit extract for antimicrobial application. Biocatalysis Agricultural Biotechnol 2020; 24: 101567.

20. Behravan M, Panahi AH, Naghizadeh A, Ziaee M, Mahdavi R, Mirzapour A. Facile green synthesis of silver nanoparticles using Berberis vulgaris leaf and root aqueous extract and its antibacterial activity. Int J Biol Macromol 2019; 124: 148-54.

21. Dakshayani S, Marulasiddeshwara M, Kumar S, Golla R, Devaraja S, Hosamani R. Antimicrobial, anticoagulant and antiplatelet activities of green synthesized silver nanoparticles using Selaginella (Sanjeevini) plant extract. Int J Biol Macromol 2019; 131: 787-97.

22. Ahmeda A, Mahdavi B, Zaker F, et al. Chemical characterization and anti-hemolytic anemia potentials of tin nanoparticles synthesized by a green approach for bioremediation applications. Applied Organometal Chem 2020; 34: e5433.

23. Zhang Y, Mahdavi B, Mohammadhosseini M, et al. Green synthesis of $\mathrm{NiO}$ nanoparticles using calendula officinalis extract: chemical charactrization, antioxidant, cytotoxicity, and anti-esophageal carcinoma properties. Arabian J Chem 2021; 14: 103105

24. Mahdavi B, Paydarfard S, Rezaei-Seresht E, Baghayeri M, Nodehi M. Green synthesis of NiONPs using Trigonella subenervis extract and its applications as a highly efficient electrochemical sensor, catalyst, and antibacterial agent. Appl Organometal Chem 2021; 35: e6264.

25. Liu Z, Zhang Z, Du X, et al. Novel green synthesis of silver nanoparticles mediated by Curcumae kwangsiensis for anti-lung cancer activities: a preclinical trial study. Arch Med Sci 2021, https://doi.org/10.5114/aoms/134059.

26. Długosz M, Markowski M, Pączkowski C. Source of nitrogen as a factor limiting saponin production by hairy root and suspension cultures of Calendula officinalis $L$. Acta Physiologiae Plantarum 2018; 40: 35.

27. You C, Han C, Wang X, et al. The progress of silver nanoparticles in the antibacterial mechanism, clinical application and cytotoxicity. Mol Biol Rep 2012; 39: 9193-201.

28. Mao BH, Tsai JC, Chen CW, et al. Mechanisms of silver nanoparticle-induced toxicity and important role of autophagy. Nanotoxicology 2016; 10: 1021-40.

29. Namvar F, Rahman HS, Mohamad R, et al. Cytotoxic effect of magnetic iron oxide nanoparticles synthesized via seaweed aqueous extract. Int I Nanomedicine 2014; 19: 2479-88.

30. Sankar R, Maheswari R, Karthik S, et al. Anticancer activity of Ficus religiosa engineered copper oxide nanoparticles. Mat Sci Eng C 2014; 44: 234-9.

31. Katata-Seru L, Moremedi T, Aremu OS, et al. Green synthesis of iron nanoparticles using Moringa oleifera extracts and their applications: removal of nitrate from water and antibacterial activity against Escherichia coli. J Mol Liq 2018; 256: 296-304.
32. Sangami S, Manu M. Synthesis of Green Iron Nanoparticles using Laterite and their application as a Fenton-like catalyst for the degradation of herbicide Ametryn in water. Environ Technol Innov 2017; 8: 150-63.

33. Radini IA, Hasan N, Malik MA, et al. Biosynthesis of iron nanoparticles using Trigonella foenum-graecum seed extract for photocatalytic methyl orange dye degradation and antibacterial applications. J Photochem Photobiol B 2018; 183: 154-63.

34. Beheshtkhoo N, Kouhbanani MAJ, Savardashtaki A, et al. Green synthesis of iron oxide nanoparticles by aqueous leaf extract of Daphne mezereum as a novel dye removing material. Appl Phys A 2018; 124: 363-9. 